\title{
The Root Cause of Migration in Southeast Asia: Apply the Migration Results Index
}

\author{
Minh Doan Van \\ Dai Viet College, Vietnam
}

\begin{abstract}
The main objective of this paper is to find out the main causes of migration and the socioeconomic benefits of labour migration in Southeast Asia. Applying the Migration Results Index (MOI) as an analytical tool revealed that the potential benefits of labour migration that have not been maximized in the region and explores the causes of the growing prevalent migration problem in Southeast Asia. The study findings that in the ASEAN region, remittances from migration have not been fully utilized, and pointed out that there are many different reasons for the migration of people in Southeast Asia throughout history, they may change their place of residence due to reasons such as economy, family reunification, study, environment. In general, each of those causes often contains factors that push and attract people to migrate. The factors driving migrants are tied to the country they are trying to leave, often issues where its consequences make people want to move. The factors that entice migrants are often attractive in countries/regions with developed conditions that attract the attention of others. The results show the need for a change in migration and development policy in ASEAN. Governments can adjust to improve migrants' job skills development opportunities, avoid large debts, support, and improve policies against illegal migration, human trafficking, and human rights protection. of migrants. migrate.
\end{abstract}

Keywords: International Labour Migration, Southeast Asia, ASEAN

*Corresponding author: Minh Doan Van; Email: minhdv.ceo1@gmail.com DOI: https://doi.org/10.37227/IJEKM-2021-04-891

\section{Introduction}

On August 8, 1967, ASEAN (Southeast Asia) was established to promote cooperation and promote regional peace and stability through compliance with the principles of the United Nations Charter (ASEAN website). Currently, there are 10 members that makeup ASEAN namely Brunei, Cambodia, Indonesia, Laos, Malaysia, Myanmar, Philippines, Singapore, Thailand, and Vietnam (Figure 1). The total population of ASEAN is 604 million (as of 2011) with a working population of at least 263 million (ASEAN Statistics, 2013), it contributes 12.8 million or $6 \%$ of the world's 216 million migrants of 3.9 million or $30 \%$ of which are migrants in ASEAN. This proportion of movements in ASEAN is growing rapidly. International migration has become an important and indispensable component of development in many countries, including Southeast Asia. It has benefited (a) migrants and their households, (b) countries in which they contribute manpower, and (c) countries of origin they transfer money, knowledge, and skills back. It also comes with economic and social costs at the household, community and national level for both submissions and receiving countries. 


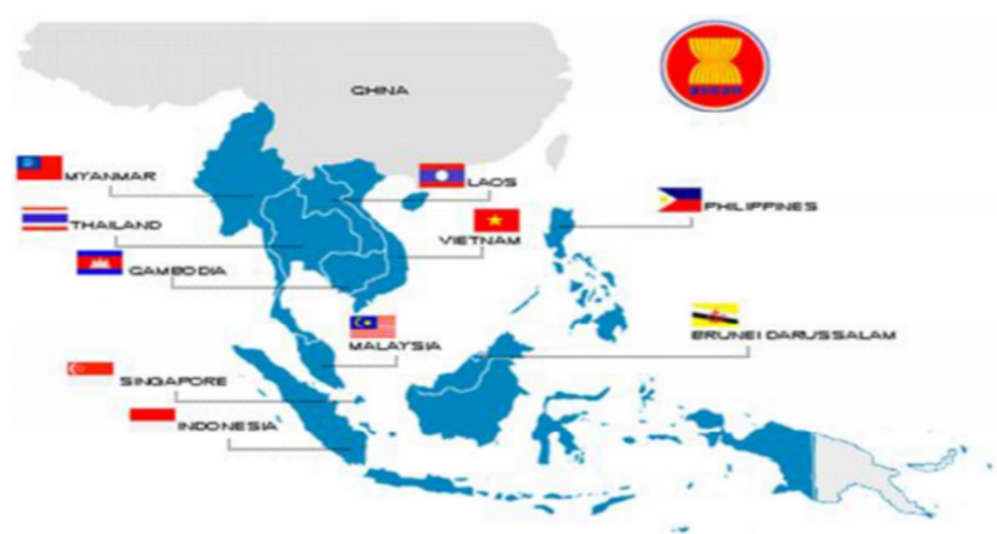

Figure 1: Map of ASEAN

In many Southeast Asian countries, migration has increased significantly including immigration and emigration, and migrants in transit by De Haas et at. (2012). It is the disparity in income levels between countries that is one of the motivations for workers from their low-income countries to go to countries they think have higher incomes. Labour migration is one of the reasons for economic growth and regional development. Migrant workers have long been an integral part of regional economies such as Malaysia, Singapore, and Thailand. In these countries, occupations that need unskilled workers such as fishing, domestic workers, or construction workers, are attractive destinations for many people from neighboring countries (Athukorala \& Manning, 1999). This also helps to increase the flow of remittances to the homeland of labour migrants. However, despite labour migration taking place in many places, migrant workers still face many difficulties and challenges related to many human rights cases such as labour exploitation, forced labour, etc. affect their benefits, legal status, and wages. Many workers are taken advantage of to work for a long time, the salary is lower than the minimum wage. This is the result of labour migrants' lack of protection and respect from employers and authorities. Therefore, understanding the origin of migration in Southeast Asia is a problem. This is a very urgent problem, which can help the government to come up with policies to help reduce human rights violations against migrants, while also using remittances more efficiently, thereby increasing living standards and develop the country.

Labour migration in Southeast Asia from the 1970s and 1980s is understood to be a constituent part of the post-colonial new migration process, the geography of migration. The scope and size of the transnational movements have grown rapidly and major countries such as Malaysia and Thailand between the two countries now account for about $70 \%$ of the estimated 13.5 million migrant workers in the region. Singapore's foreign workforce accounts for $25 \%$ of the country's workforce. Two phenomena characterize these labour moves like western democracies that import labour, major labour importing countries in Southeast Asia rely on guest workers to solve their labour shortages by Lai et al. (2013). Over the past two decades, labour migration has emerged as an important engine of economic growth and development in both the exporting country and the migrant country in the ASEAN region.

As Graeme Hugo (2012) stated that labour migration is one of the characteristics of Southeast Asian countries. What complicates any attempt to create meaning on migration in Southeast Asia are Hug o's (2004) remarks, the vast scale and complex culture, ethnicity, politics, religion, and economy of the region. For this reason, the region defies all 
kinds of generalizations. The study of contemporary migration in Asia is dominated by the claim that migration is an economic phenomenon; therefore, excessive interest in labour migration caused social, political, and cultural damage (Asis and Piper 2008).

To look at the issue of international migration in Asia, more than 53 million (28\%) of the estimated 191 million international migrants in 2005 were from the region; most of them are inland (Asis and Piper, 2008). Migration between regions in Southeast Asia (ASEAN) is particularly important. In 2011, ASEAN accounted for more than $32 \%$ of the world's total overseas travel (Aldaba, 2014). In the region, migrants abroad from Malaysia mainly arrive in Singapore, migrants from Myanmar are drawn to Thailand, and Indonesians are drawn toward Malaysia. The region has two of the world's largest labor exporting countries: namely, the Philippines has scattered citizens around the world including the Middle East and Indonesia (Asis and Piper, 2008). Other main sources of labor in Asia are South Asian countries. The Bangladeshi community is as popular as Filipinos, especially in the Middle East and Malaysia.

Although a very urgent issue, previous studies only made general statements without specifying the underlying causes of migration in Southeast Asia affecting the policy and effectiveness of migration policy application to migration in Southeast Asia. Therefore, in this study, the author has applied the Migration Outcomes Index (MOI) as a tool to examine the root problems of Southeast Asian migration and the potential benefits of labour migration. It has since become a good document and platform for stakeholders, especially country-makers, in various decision-making processes related to migrants.

\section{Define Migration}

\section{Literature Review}

Migration has long been a concern of most countries in the world. The movement of citizens of a country within its territory or across national borders is one of the important policy topics, especially in the context of globalization and international integration. The flow of capital, goods, and information across borders is inevitable. Along with these flows, waves of workers leaving their homeland in search of better economic opportunities are increasing (Stuart Hall, 2000). According to estimates by the International Organization for Migration, in 2005 there were 240 million international migrants, compared with only 60 million ten years earlier (IOM, 2005). According to United Nations projections, by 2050 there will be about 290 million inter-country migrants (UN, 2002). It can be said that compared with factors of political instability, socio-economic, war, natural disaster, climate change, economic factors such as low income, poverty, underemployment and choosing a livelihood is the dynamic main force in migration decisions. The disparity in living standards and job opportunities with higher incomes in the country have pushed migrants to find new opportunities, even if only temporarily time abroad. Migration for economic purposes is the dominant type of migration, especially in the context of globalization and economic freedom.

The issue of labour migration in Southeast Asia developed in the 1960s and expanded in the 1970s and 1980s. After the oil shocks of the 1970s, the oil-rich Gulf countries established the construction industry and large development projects that attract a significant number of migrant workers from South and Southeast Asia (Athukorala \& Manning, 1999). Thailand, the Philippines, and Indonesia see this opportunity as an economic lifeline and start programs to deploy workers abroad to benefit from job opportunities in the Middle East. Subsequently, Singapore and Malaysia also experienced

International Journal of Education and Knowledge Management (IJEKM) 
labour shortages and became attractive destinations for temporary labour mobility in the region (Asis and Piper, 2008). The growing economic and political linkages within and between countries in the region, especially after the formation of the Association of Southeast Asian Nations (ASEAN), have also promoted the personal mobility of individuals multiply. As economic and demographic disparities between states become increasingly apparent, local geographic and regional contexts take on greater importance in shaping and facilitating flows of cross-border workers in Southeast Asia (ILO and ADB, 2014).

\section{Cause of Migration}

Asis and Piper (2008) said that during modern migration in Southeast Asia, the movement of workers due to the need for low-skilled and skilled people has dominated the interests of research and axis since the 1970s. More specifically, these workers include the range of skilled sellers in the construction industry, the very central service sector of the consumer economy including the need for domestic help and care, and the so-called demand for foreign talent in the knowledge economy. What such workers have in common is that most of them live in an urban-based economy (Orbeta, 2013). The origin of such an economy can be derived from the formation and expansion of world markets ended by the process of European exploration and colonies more than 300 years ago. Now known as the globalization of the argument, the process has assumed new and intensified forms since it was recognized by social scientists as an important economic process in the mid-1980s, with widespread popularity. socio-political consequences. As Stuart Hall described in (2000), "Contemporary globalization is associated with the rise of new financial markets, non-regulatory, with global capital and currency flows large enough to destabilize medium-sized economies, transnational forms of production and consumption, the anathematizing growth of new cultural industries supported by new information technology and the rise of the knowledge economy." All in all, globalization is the main responsibility in promoting international mobility and the movement of the population, especially from the labor-intensive economy to the labour deficit economy.

The majority of migration studies focus on the movement of populations as a synthetic phenomenon, which is clearly or implicitly understood if not a consequence of adversity and attraction, the so-called push and pull pressure. Such views have provided information for ordinary migration research that is valuable in providing us with an overall view and extent of people's movement in the past as well as the present. However, the synthesis of mobility, Lindquist (2010) points out, obscures the peculiarity of those motions. People move for a variety of reasons - not always obvious to them - but they must be well aware of the uncertainty that comes with migration in their way and from their cultural point of view. It is often ignored that migration is a very humane and emotional experience that can only be understood in its cultural context. The Minangkabau people of Sumatra when wandering refer to meranti (circular migration), forcing them to return home, and are considered a ritual of travel (Kato-Lindquist, 2010). Samar villagers, one of the Visayas islands in the Philippines, view their migration from a swerve perspective, seeking luck to improve a person's life (Hosoda, 2008). Bangladeshi migrants arriving in the UK from Sylhet district have developed a two-faced orientation in managing the mental stress that comes with migration: between their homeland or refuge, the source of their personal and religious stupidity, and abroad (bides) where they seek economic opportunity and success.

International Journal of Education and Knowledge Management (IJEKM) 
There is a temporal dimension to international migration in Southeast Asia that is easily overlooked as much of migration scholarship has and is focused on labour movements under conditions of globalization. It is not always appreciated that the scale of migration in the colonial years was no less significant than contemporary migration. Asian labour migrations to Southeast Asia in the late nineteenth and early twentieth centuries coincided with the growth of world trade in commodities, European territorial expansion, and the development of commercial and trading networks (Kaur, 2013). It was estimated that between 1911 and 1929, gross migration into Burma, British Malaya, and Thailand was more than twice the gross migration into the United States; and even though a high proportion of these migrants returned home, the net inward migration was about 1.55 million (Huff and Giovanni in Kaur 2013). Furthermore, Southeast Asia had a much faster population growth in the late nineteenth and the first half of the twentieth century than either China or India (Maddison in Kaur, ibid.). The labour movements of the colonial period were fuelled by growth in the world demand for commodities, namely rubber, tin, rice, and sugar. The majority of descriptive studies and experimental data focus on documenting migrant labour flows and the creativity of policy policies. However, if migration is considered more than an economic phenomenon then we can assess how diverse it is as a social and human experience. Such an attempt to capture some of the diversity of the migration experience, in terms of time and space, was made in a collection of recent contributions by Lai et al. (2013). As we grasp the diversity of migration trajectories in the intersections of the usual influx of people noted by the state and official academics, we can see the experience of migration can be seen in a novel way: as the fault between the present and the past, as memories and representations, as well as the location and creation of identity.

\section{Social Benefits of Migration}

Firstly, Migrant workers also benefit from migration due to the significant wage disparity among ASEAN countries, thus providing an opportunity for workers from low-wage countries to benefit significantly by the simple way is to move to other countries. go over the border too. Singapore's average monthly salary in 2013 was 3,694 USD, 30 times higher than in Cambodia. Malaysia's average monthly salary is three times higher than that of Indonesia, the Philippines and Vietnam (ILO 2014).

Secondly, even family members benefit from receiving remittances to increase the budget and reduce poverty. In 2015, about 62 billion USD was transferred to ASEAN countries. Total remittance is equal to $10 \%$ of the GDP of the Philippines, $7 \%$ of Vietnam, $5 \%$ of Myanmar and 3\% of Cambodia. Remittances help countries eliminate hunger and reduce poverty. In studying 71 low- and middle-income countries, Adams, and Page (2005) estimated that a $10 \%$ increase in remittances would reduce poverty by $3.5 \%$. In the Philippines, households sending members abroad are two or three times more likely to escape poverty (Ducanes 2015). Similar positive effects were found in Indonesia and Vietnam (Adams, Cuecuecha 2014; Nguyen 2008).

In addition to directly benefiting workers, international migration has a wide-ranging positive impact on the economy. The impact of migration on economic growth is important because it determines whether those who benefit from migration can compensate those who are displaced (Felbermayr, Kohler 2009). Evidence from ASEAN shows that migration has a positive impact on economic growth. In Malaysia, for example, simulation studies show that a real increase in unskilled migrant workers of $10 \%$ leads to a real GDP

International Journal of Education and Knowledge Management (IJEKM) 
increase of $1.1 \%$ (Ahsan et al. 2014). In Thailand, recent analysis shows that without a migrant workforce, GDP would fall by $0.75 \%$ (Pholphirul, Kamlai, Rukumnuaykit 2010). However, although there is some concern about the possible negative effects of "brain drain" in host countries, these effects are likely to be over-and exaggerated by the phenomenon gray matter circulation". The migration rate of skilled workers in some ASEAN countries is quite high, $15 \%$ in Cambodia and Laos, about $10 \%$ in Vietnam and Singapore. (Özden, Phillips 2015).

The above studies reflect the work of scholars actively involved in the study of migration in Southeast Asia. They are often related to many of the issues discussed in this introduction, but they also capture the specifics of regional migration experiences. The following accounts summarize the phenomenon of migration, but they also show in between that migrants must cross the boundaries of cultures and cross borders excluded by countries. family. put. Contributions to this booklet reflect the richness and diversity of people moving to and from the area and how they manage the risks and uncertainties that come with leaving home.

\section{Methodology}

The study developed the main analytical tool, it is quantitative method-the Migration Outcomes Index (MOI). The MOI provides a quick measure of migration impact by generating a score that combines four financial and four social indicators to assess changes from pre-migration to post-migration. Much like the intent in establishing the Human Development Index in 1990, it was created "to shift the focus from national income accounting to people-centered policies" (Fukuda-Parr, 2003). It also represents a break from the very dominant human trafficking paradigm within Southeast Asia, offering a more nuanced assessment of migration outcomes rather than the overly simplistic binary of trafficked or not trafficked.

MOI scores are calculated at the individual respondent level and indexed on a range of $0-100$ to provide an accessible benchmark against which to measure progress. The benefits of a single number score are that it facilitates comparisons between different groups of migrants and allows for factors that contribute to positive or negative migration outcomes to be more easily identified.

A large survey took place in July and August 2016 with a total of 1,808 migrant workers returning home in Cambodia, Lao PDR, Myanmar and Vietnam. (Table 1). The number of survey respondents is evenly distributed in all 4 countries. In addition, 96 migrant workers and stakeholders were interviewed. The study is designed to understand migration from a regional level, providing comparative data between migrant countries and immigrant countries and migration corridors in Southeast Asia. A regional fundamentals investigation into labour migration in Southeast Asia conducted by the International Labour Organization (ILO) 'Tri-party action to strengthen labour migration contribution to growth and development in ASEAN' (TRIANGLE in ASEAN) and International Organization for Migration (IOM) 'Reducing poverty through Safe Migration, Skills Development and Employment Enhancement in Cambodia, Lao People's Democratic Republic (Lao PDR), Myanmar, Thailand and Vietnam' (PROMISE project). 


\section{Table 1: Research Sample}

\begin{tabular}{|c|c|c|c|}
\hline Respondent & Location & Criteria & Sample Size \\
\hline $\begin{array}{l}\text { Return migrant } \\
\text { workers }\end{array}$ & $\begin{array}{l}\text { Cambodia } \\
\text { Lao PDR } \\
\text { Myanmar } \\
\text { Viet Nam }\end{array}$ & $\begin{array}{l}\text { - } \quad 18-45 \text { years of age } \\
\text { Returned from work in } \\
\text { Thailand or Malaysia during } \\
\text { the last two years } \\
\text { - } \quad \text { womployed in low-skilled } \\
\text { work in fisheries, domestic } \\
\text { work, agriculture, } \\
\text { manufacturing, } \\
\text { construction or hospitality } \\
\text { and food services. } \\
50 \% \text { women } / 50 \% \text { men }\end{array}$ & $\begin{array}{l}\text { Survey }(n=1,808) \\
\text { In-depth interviews }(n=60)\end{array}$ \\
\hline Stakeholders & $\begin{array}{l}\text { Cambodia } \\
\text { Lao PDR } \\
\text { Myanmar } \\
\text { Viet Nam }\end{array}$ & $\begin{array}{l}\text { Equal representation of (1) } \\
\text { government officials; ( } 2 \text { ) } \\
\text { recruitment agencies and } \\
\text { employers; and (3) trade } \\
\text { unions, NGOs, mass } \\
\text { organizations and women's } \\
\text { groups. } \\
\text { - } 50 \% \text { women/50\% men (to } \\
\text { the extent possible) }\end{array}$ & $\begin{array}{l}\text { Key informant interviews } \\
(n=36)\end{array}$ \\
\hline
\end{tabular}

Source: author's synthesis

To assess the impact of migration on socio-labor development, a measure of zero is required in the year of implementation of one of the projects. The research will also be used to shape the design of interventions by identifying key gaps in policies and practices that need to be addressed. This draft is drawn from the results of a broader ILO/IOM study, which documents the application of a methodology developed in partnership with management consulting firm Rapid Asia to measure outcomes. labor mobility. of migrant workers through a socioeconomic index.

\section{Profile of Return Migrant Workers Surveyed}

As shown in Table 2, most migrants from all countries work in Thailand, except those from Vietnam, who are evenly divided between Thailand and Malaysia. There is no clear model in the field of employment, with construction for Cambodians (46\%), hotel and dining services for Laos (32\%), production for Myanmar (37\%) and fisheries for Vietnamese $(29 \%)$ are the most common types. undertaken work, respectively. Unsurprisingly, the ethnicity of migrant workers in Myanmar is much more diverse, with more than half coming from ethnic minority groups $(57 \%)$. Due to the data collection locations, the migrants Shan and Kayin represented the largest ethnic minority groups surveyed. Ethnicity is an important factor in in affecting migration patterns in Myanmar because the long tradition of cross-border migration exists largely based on ethnic or related links (Hein and associates, 2015).

Vietnamese pay the most migrant costs $(\$ 709)$, must borrow the largest amount $(\$ 1,044)$ and take the most time to pay back (11 months), much of which may be due to higher rates of regular migrant workers. Malaysia through recruitment units. In contrast, only about a quarter of Lao migrants must borrow any money to migrate to Thailand, at an average cost of US\$171 and account for an overwhelming proportion through insular channels $(96 \%)$. 
Table 2: Profile of Return Migrants by Country of Origin

\begin{tabular}{|c|c|c|c|c|c|}
\hline Destination Country & $\begin{array}{c}\text { Cambodia } \\
n=457 \\
(\%)\end{array}$ & $\begin{array}{c}\text { Lao PDR } \\
n=450 \\
(\%)\end{array}$ & $\begin{array}{c}\text { Myanmar } \\
\mathrm{n}=451 \\
(\%)\end{array}$ & $\begin{array}{c}\text { Viet Nam } \\
\begin{array}{c}n=450 \\
(\%)\end{array}\end{array}$ & $\begin{array}{c}\text { Total } \\
\mathrm{N}=1,808 \\
(\%)\end{array}$ \\
\hline Thailand & 92 & 100 & 71 & 51 & 81 \\
\hline Malaysia & 8 & - & 29 & 49 & 19 \\
\hline Work Sector & $\%$ & $\%$ & $\%$ & $\%$ & $\%$ \\
\hline Domestic Work & 7 & 14 & 8 & 13 & 11 \\
\hline Fisheries & 4 & 4 & 4 & 29 & 10 \\
\hline Agriculture & 8 & 16 & 27 & 2 & 13 \\
\hline Manufacturing & 29 & 24 & 37 & 27 & 29 \\
\hline Construction & 46 & 11 & 13 & 14 & 21 \\
\hline Hospitality and Food Service & 5 & 32 & 12 & 15 & 16 \\
\hline Ethnicity & $\%$ & $\%$ & $\%$ & $\%$ & $\%$ \\
\hline Majority & 96 & 96 & 43 & 100 & 84 \\
\hline Minority & 4 & 4 & 57 & - & 16 \\
\hline Key Migration Statistics & $\# / \% / \$$ & $\# / \% / \$$ & $\# / \% / \$$ & $\# / \% / \$$ & $\# / \% / \$$ \\
\hline Median number of years abroad & 1 & 2 & 3 & 4 & 3 \\
\hline Average cost of migrating (US\$) & $\$ 255$ & $\$ 171$ & $\$ 587$ & $\$ 709$ & $\$ 430$ \\
\hline Borrowed money to pay for migration & $48 \%$ & $28 \%$ & $39 \%$ & $52 \%$ & $42 \%$ \\
\hline Average loan amount (US\$) & $\$ 241$ & $\$ 152$ & $\$ 596$ & $\$ 1,044$ & $\$ 560$ \\
\hline Average months to pay back loan & 5 & 3 & 10 & 11 & 8 \\
\hline Average number of days worked per week & 6.6 & 6.4 & 6.4 & 6.3 & 6.4 \\
\hline Average number of hours worked per day & 10 & 9 & 11 & 10 & 10 \\
\hline Average monthly income (US\$) & $\$ 268$ & $\$ 274$ & $\$ 176$ & $\$ 357$ & $\$ 268$ \\
\hline Worked without legal documents & $35 \%$ & $46 \%$ & $46 \%$ & $48 \%$ & $44 \%$ \\
\hline
\end{tabular}

Source: author's synthesis

Working conditions are very demanding, with migrants from all countries having to work 9-11 hours a day for more than 6 days a week. Most migrants earn below the legal minimum wage 3 despite working long hours but there are significant differences between countries. Workers earn more than double the wages of Myanmar migrants (\$357 versus \$176) even though they work fewer hours.

There is a significant wage gap between women and men migrating for all four nationalities, with salaries $14 \%$ higher overall. Categorial data analysis to determine whether differences are made by high-sex work sectors shows large disparities for all types of employment, except in the manufacturing and hospitality/food sectors.

\section{Causes of migration}

\section{Results}

First of all, there is an economic cause. Migration is defined as the difference in income, attractiveness between economies and living conditions. The Harris Todaro (Harris-Torado Model) theory of expected income states that labor market participants, both real and future, compare their expected earnings over a certain period in an urban area (or weigh the benefits and harms of migration) with the average income available in the countryside and 
will migrate if income expectations are high than current income. In addition, migration is identified as a result of the difference in labor demand in the labor market between developed and developing countries (Hollweg và et at, 2014).

Secondly, it is a matter of migration for family reunification. Among the underlying causes of international migration, family reunification also occupies an important place. This is a very common phenomenon and is often associated with people with developing or underdeveloped economies like Southeast Asian countries today (Batalova et at, 2017). The advantage of family reunification is that it can reduce many risks during migration, especially for women and children, who tend to be more dependent than men during migration this program.

The third reason is migration because of environmental problems. Environmental change is always accompanied by social, demographic, or economic challenges. Environmental degradation seems to be a proximate cause of migration, while the underlying factors are population pressure and resource use patterns Astri Suhrke (1994). The degradation of the environment is closely related to the development of economies and people's living standards. Natural disasters and floods can cause acute migration, but soil pollution, water or sea-level rise will lead to permanent migration. Clearly, large-scale demographic shifts are always driven by changes in the environment and related processes. With the survival instinct, people must look to places with natural conditions for life. Therefore, environmental variability is also considered to be a major driver of international migration.

Last but not least, the globalization of the labor market is an important condition for promoting international migration. Through global media, the opportunities and attractiveness of developed economies are communicated to people in developing countries, making them ready to face the challenges and risks of migration (Kaur, 2008, 2009).

In summary, the causes of migration can be many, but in general, the above causes can be considered as the main causes of migration in developing countries in the region of Southeast Asia. Those causes may be mandatory but also express the free will and aspirations of people.

\section{Socio-economic benefits of labour migration in Southeast Asia}

Table 3: Migration Outcome Index Indicator

\begin{tabular}{|l|c|c|}
\hline Social Indicators & Positive Outcome & Negative Outcome \\
\hline Life skills development & Improved & No change \\
\hline Unemployed & No & Yes \\
\hline Skill level of work & Improved & No change or reduced \\
\hline Psychological, social or health problems & No & Yes \\
\hline Financial indicators & Positive Outcome & Negative Outcome \\
\hline Income & Increased & No change or reduced \\
\hline Tangible assets & Increased & No change or reduced \\
\hline Savings & Increased & No change or reduced \\
\hline Debt & No & Yes \\
\hline
\end{tabular}

International Journal of Education and Knowledge Management (IJEKM) 
Table 3 shows the factors that directly affect migration. In terms of social indicators, the increase in life skills, the decrease in the unemployment rate among migrants, the increase in working skills for the new working environment. At the same time, one of the most important factors is financial literacy, increasing income, as well as increasing savings and reducing debt ratio. Thereby, migration brings great benefits to migrants both in terms of social indicators and financial capacity. The results are fairly balanced between positive social and financial outcomes, which suggests that migration has led to a range of complex changes in the lives of migrant workers that should not be simplified too. Researchers have shown that a limited focus on migrants' potential to contribute to development through the exploitation of their financial resources can lead to stagnation, shifting attention away from the necessary economic and political structural reforms in the countries of origin (De Haas, 2012). A World Bank study reached the same conclusion, warning that remittances are not a magic bullet for long-term development in Asia (Ahsan et al., 2014).

One of the factors that is said to be the most concerned by immigrants is financial issues, so it is the most concerned interest. Migration and remittances help change the mindset of the production force. In addition to the relative income abroad, people who go to work abroad have the opportunity to approach new production methods, accumulate capital, receive vocational training, experience, working skills and labour discipline when returning to the country. These are considered important factors that change the domestic production force. With remittances attracted to the country, the remittance country gradually shifts from a labor-based economic development strategy to a capital-based economic development strategy. Even with the agricultural sector, which is considered a traditional profession of the household, when returning, workers make changes in the manufacturing industry, applying skills, knowledge, and technology to increase labour productivity. In the long term, the quality of labour resources changes, creating opportunities for the next generation to access more skilled jobs with higher wages (Hoddinott and Francis, 1993), contributing to the restructuring of production and labor in the economy.

All Vietnamese migrants send money back home with an average remittance of USD 245 from Thailand and USD 162 from Malaysia. In general, deposits of Vietnamese migrant workers are used to support their family members $(60 \%)$. Although access to the migrant financial system is generally very low, Vietnamese migrants are the exception in the region. In Vietnam, $28 \%$ of migrants have bank accounts and $42 \%$ open bank accounts while abroad. This may be because Vietnam has a more formal remittance market than other countries of origin.

\section{Discussions}

The results of this study show that although the socio-economic benefits of labor migration have not been maximized in the ASEAN region, positive results can be achieved if migrant workers are created opportunities to improve career skills, avoid large debts, receive minimum wages, and find useful employment upon return. To support better implementation of those outcomes, a change in approach to migration and development policy is needed (Özden, Phillips 2015). Along with that, the targeted adjustment is to increase the number of migrant workers with a comprehensively beneficial labor migration experience rather than simply expanding the national remittance account. The methodology 
for assessing the outcomes of migration into low-skilled work has proven very useful to the ILO and IOM projects for which it was designed.

Migrants in Southeast Asia demonstrate significant determination while striving to live safely and earn a livelihood. What choices they have, however, are not easily facilitated within ASEAN state practices, including the current regional integration process. Rather, refugees and migrants resort to an exploitative (and adaptive) shadow migration industry that profits from the demand to circumvent state limits on movement and membership. Attempts to combat smuggling/trafficking as a criminal justice issue, however, will not help the Rohingya and other forced migrants if the denial of access to a state and its protection continues.

Protection of labour rights in immigrant countries is the most important factor in facilitating more positive results for migrant workers; especially ensuring workers receive the minimum wage. This is our recommendation for the policymakers in these countries. This suggests that formalizing the working conditions of migrant workers who are often excluded from the statutory minimum wage requirement is an important step towards ensuring migrant workers benefit from their migrant experiences. The lack of assurance of labour protections leading to migration in ASEAN is often seen as a blessing for migrant workers and their families. Migrants are now less likely to control whether they experience good or bad migration, no matter how they make decisions. On the larger side, strengthening the positive impact of migration requires changes in the policies and practices of those responsible for the realities of rights: government officials, employers, and recruitment companies rather than changing the behavior of migrant workers.

With strong migration pressure along with a lack of demand for mass labor migration will lead to a more controlled and effective migration policy. These will be developed in tandem with a commitment to allowing highly skilled people to easily access the labour market. As a result, receiving countries will develop a range of entry policies that allow and even encourage the immigration of people with the skills they handle, while trying to limit the entry of those with others. Especially for Southeast Asian countries with a high migrant population, it is advisable to control the source of migration, along with providing the best protection policies for human rights for residents, and effectively use remittances fruit.

\section{Concluding Remarks}

Overall, this study finds the benefits of migration on social life through financial growth for migrants as well as their families, thereby also increasing remittances to help develop land country. At the same time, migration also helps migrants gain more knowledge and skills for the new environment. However, there are still some weaknesses concerning migration, through which the Government can introduce several policies to regulate migration as well as use remittances more effectively:

From the above issues for countries that receive a lot of migrant workers, it is necessary to accelerate the transformation of the growth model towards the development of industries and fields with high technology content, using technology. employ fewer workers, while promoting hard and soft infrastructure planning options for migrant workers. There should be a plan to allocate revenue from reallocating investments in infrastructure to migrants to ensure the sustainability of development. Along with that, it is necessary to integrate gender factors in-migration into the process of ensuring the sustainability of development. Integrating the gender factor in-migration into the process of 
developing strategies and plans for medium-term and annual socio-economic development of localities.

For countries with a large number of migrants, the study recommends accelerating economic restructuring towards industry and services, to promote economic development and help create jobs for local workers. In the immediate future, it is necessary to focus on planning the development of soft infrastructure, including mechanisms, policies, and implementation plans in the direction of protecting and taking care of children, the elderly, lonely people, and the elderly. well-structured luggage for migrants so no one is left behind.

\section{References}

Aldaba, F. T. (2014). Migration governance in the ASEAN economic community. In G. Battisella (Ed.), Global and Asian perspectives on international migration. Switzerland: Springer International Publishing.

Ahsan, Ahmad, Manolo Abella, Andrew Beath, Yukon Huang, Manjula Luthria, (2014). International Migration and Development in East Asia and the Pacific. Washington, DC: WB.

Athukorala, P., \& Manning, C. (1999). Structural change and international migration in East Asia. Melbourne: Oxford University Press.

Asis, Maruja M.B and Nicola Piper (2008). Researching international labor migration in Asia the Sociological Quarterly, vol. 39, No. 3 (Summer), pp. 423-444.

Asis, Maruja M.B. (2008b). How international migration can support development: a challenge for the Philippines. In Migration and Development: Perspectives from the South, edited by Stephen Castles and Raul Delgado-Wise. Geneva: International Organization for Migration, pp. 175-202.

Association of Southeast Asian Nations (ASEAN). (2016). ASEAN Economic Community at a Glance. Available at: http://asean.org/storage/2015/11/AECat-a-glance2016_web_version2.pdf [05/09/2021].

Adams, Richard H., A. Cuecuecha. 2014. "Remittances, Household Investment, and Poverty in Indonesia.", Managing International Migration for Development in East Asia, Washington, DC: WB.

Adams, Richard H., John Page. (2005). "Do International Migration and Remittances Reduce Poverty in Developing Countries?”. World Development Magazine. No.33 (10): 1645-69.

Batalova, Jeanne, Andriy Shymonyak, Guntur Sugiyarto, (2017). Firing up Regional Brain Networks: The Promise of Brain Circulation in the ASEAN Economic Community. Manila.

De Haas, H. (2012). 'The migration and development pendulum: A critical view on research and policy, In International Migration, Vol. 50, Issue 3.

Francis, E., and J. Hoddinott, "Migration and differentiation in Western Kenya: A tale of two sub-locations," Journal of Development Studies, Vol. 30, No. 1 (October 1993), pp. 115-145.

Fukuda-Parr, S. (2003). 'The Human Development Paradigm: Operationalizing Sen's Ideas on Capabilities'. In Feminist Economics, Vol. 9, pp. 310-317.

Felbermayr, Gabriel J., Wilhelm Kohler. (2009). "Can International Migration Ever Be Made a Pareto Improvement?".The Integration of European Labour Markets, Ewald Nowotny, Peter Mooslechner, 32-50. Cheltenham, Anh: NXB Edward Elgar 
Graeme Hugo (2012). "Village-communities, village norms, and ethnic and social networks: A review of evidence from the Third World," in Gordon F. DeJong and Robert W. Gardner (eds.), Migration Decision Making: Multidisciplinary Approaches to Microlevel Studies in Developed and Developing Countries. New York: Pergamon Press, pp. 186-225.

Hugo, G. (2004). International migration in Southeast Asia since World War II'. In A. Ananta \& E. V. Arifin (Eds.), International migration in Southeast Asia. Institute of Southeast Asian Studies: Singapore.

Hollweg, Claire. (2016). "Labor Mobility and Labor Market Integration in ASEAN", WB, Washington, DC.

Hosoda, N. (2011). Philippines: A nation exploring opportunities in the world labor market. In W. Asato (Ed.), Rodo-sakoku nippon no hokai: Jinko-gensho-shakai no ninaite wa dareka (The end of labor closed-door policy of Japan: Who will take care of the aging society?) (pp. 179-194). Tokyo: Diamond Publishing Co.

Hosoda, N. (2013). Kababayan Solidarity. Filipino communities and class relations in United Arab Emirates cities. Journal of Arabian Studies: Arabia, the Gulf, and the Red Sea,3(1), 18- 35.

Hosoda, N. (2015). 2008: Open city and a new wave of Filipino migration to the Middle East. In E. Tagliacozzo, et al. (Eds.), Asia inside out: Changing times (pp. 281303). Cambridge: Harvard University Press.

Hosoda, N., \& Watanabe, A. (2013). Impacts of religious conversion on social relations of Filipino migrant workers in the Arab Gulf States: Cases of bornagain Christians and newMuslims. Hakusan Review of Anthropology, 16, $29-53$.

Hein, A., Minoletti, P., Paing, A., Win, N., Harkins, B. (2015). Safe migration knowledge, attitudes and practices in Myanmar. Bangkok: ILO.

ILO. (2014). Profits and poverty: The economics of forced labour. accessed 17 June 2021

International Labour Organization (ILO) and Asian Development Bank (ADB). (2014). ASEAN community 2015: Managing integration for better jobs and shared prosperity. Bangkok.

Kaur, A. (2008). International migration and Governance in Malaysia: Policy and performance. UNEAC Asia Papers. 22, 4-18.

Lai C. H., Lin C. Y., Chen C. H., Gwung H. L., Li C. H. (2013). "Can internet usage positively or negatively affect interpersonal relationship?" in Smart Innovation, Systems and Technologies Vol. 20 eds Chang R. S., Jain L.C., Peng S. L. (Berlin: Springer;) 373-382.

Lindquist, J. A. (2010). The anxieties of mobility: Migration and tourism in the Indonesian Borderlands. Singapore: NUS Press.

Özden, Çağlar, Mathis Wagner. (2016. “Immigrant versus Natives? Displacement and Job Creation." WB, Washington, DC.

Orbeta, A. (2013). Enhancing Labour Mobility in ASEAN: Focus on Lower Skilled Workers. Discussion. Paper Series No. 2013-17, PIDS, available at www.pids.gov.ph/dp.php?id=5153\&pubyear $=2013$

Stuart Hall (2000). Articulations of race, class and identity. Ethnic and Racial Studies: $37(10)$.

Pholphirul, Piriya, Jongkon Kamlai, Pungpond Rukumnuaykit. (2010). “Do Immigrants Improve Thailand's Competitiveness?". WB, Washington, DC 